\title{
IMPACT OF WEATHER CONDITIONS ON SEASONAL DEVELOPMENT, POPULATION STRUCTURE AND REPRODUCTIVE SUCCESS ON DACTYLORHIZA TRAUNSTEINERI (ORCHIDACEAE) IN THE KOMI REPUBLIC (RUSSIA)
}

\author{
Irina A. Kirillova*, Dmitry V. Kirillov \\ Institute of Biology of the Komi Scientific Centre, Ural Branch of RAS, Russia \\ *e-mail: kirillova_orchid@mail.ru
}

Received: 23.12.2019. Revised: 20.03.2020. Accepted: 23.03.2020.

\begin{abstract}
Due to specific biological features, high ornamental value and low resistance to anthropogenic factors, Orchidaceae species belong to the most vulnerable plants. To successfully protect their populations, comprehensive investigations of orchid biology and ecology are necessary. Long-term population studies are the most valuable. The paper presents data of population studies of Dactylorhiza traunsteineri, an orchid species listed in the Red Data Book of the Russian Federation. The field investigations have been conducted in the Komi Republic where the orchid species is located at the northeastern limit of its range. The seasonal development of $D$. traunsteineri lasts from May to August. We found the weather factors (air temperature, precipitations) impact features of small and big life cycles of this orchid species. The size of plant individuals is influenced by weather conditions of both the current and previous vegetative season. The number of generative (flowering) individuals per population had a positive correlation with the air temperature and humidity in August of the previous vegetative season. The fruit set of $D$. traunsteineri is high $(50.4 \%)$. This parameter is negatively correlated with the air temperature at the flowering period, while it is positively correlated with precipitation values. The seed number per capsule (4090 seeds in average) was higher than it is known for other Dactylorhiza species in the Komi Republic. The real seed production is associated with the moisture content level during the vegetative season. The seed production of D. traunsteineri was high, from 88000 to 199000 seeds per $1 \mathrm{~m}^{2}$ in different study years. The presence of juvenile individuals (3.5-9.4\%) over all study years indicates a successful seed reproduction in this population. This parameter was positively correlated with precipitation, air temperature in August, and seed production at the previous vegetative season.
\end{abstract}

Key words: climate influence, fruit set, monitoring, orchids, population structure, seed production

\section{Introduction}

Orchidaceae is one of the largest families among flowering plants (Christenhusz \& Byng, 2016). At the same time, the majority of orchids are rare, endemic, and threatened (Cribb et al., 2003). Orchid vulnerability is mainly associated with biology features, such as unique «orchid mycorrhiza», low competitiveness, and high specialisation of pollination (Shefferson et al., 2019). To successfully protect orchid populations in nature under conditions of anthropogenic pressure, comprehensive studies of ecology and biology of these vulnerable plants are necessary (Fay, 2018). Despite of a high interest in these plants, numerous issues of orchid biology are still unsolved. This is partially explained by the short-term character of most of the studies worldwide. But such results do not allow correctly assessing the current status of orchid populations and understanding their future survival prospects (Vakhrameeva et al., 2011). In this relation, the long-term studies of orchid populations at the fixed study plots are the most valuable. The long-term demographic investigations provide the inestimable data to understand how and why natural orchid populations are changed in terms of their size and structure (Hutchings, 2010). The need of monitoring populations of threatened orchid species was indicated also by Wraith et al. (2020) in a study devoted to an analyse of gaps and priorities in investigation and conservation of these vulnerable plants. The first demographic studies of orchids were published by Tamm (1948, 1972), Inghe \& Tamm (1988). At present, the majority of monitoring investigations are devoted exactly to orchids (Kull, 2002; Kull et al., 2008). But even taking into account numerous recent publications (e.g. Vakhrameeva, 2006; Blinova, 2008, 2009; Puchnina, 2017; Brzosko, 2002, 2003; Pfeifer et al., 2006; Shefferson, 2006; Jacquemyn et al., 2007; Hutchings, 2010; Sletvold et al., 2010a; Van der Meer et al., 2016; Dibble et al., 2019; Stroh, 2019), many issues of orchid population dynamics are still poorly studied.

In the present paper, we have studied the impact of weather factors (air temperature and 
precipitation) on the reproductive success and population structure of a threatened orchid, Dactylorhiza traunsteineri (Saut. ex Rchb.) Soó s.l., at the northeastern limit of its range within the Komi Republic (Russia). Dactylorhiza traunsteineri is listed in the Red Data Book of the Russian Federation (2008) with category 3 (rare species). However, in Russia, this species has not been actually investigated (Vakhrameeva et al., 2014), except for the study of Blinova \& Uotila (2012) in the Murmansk region. There are a few publications conducted in Norway (Øien \& Pedersen, 2003; Øien et al., 2008; Sletvold et al., 2010a,b, 2013; Sletvold \& Agren, 2011, 2014, 2015) and devoted to the study of biology features of a closely related species, Dactylorhiza lapponica (Laest. ex Hartm.) Soó, which is sometimes considered as conspecific to D. traunsteineri s.l.

\section{Material and Methods}

Dactylorhiza traunsteineri (Saut. ex Rchb.) Soó s.1. is a rare orchid protected in many Eu- ropean countries (Kull et al., 2016). This is predominantly a European species (Fig. 1a). Within its range, this orchid inhabits open Sphagnum mires of transitional and raised types, with increased mineral nutrition, and spring fens. In the Komi Republic, (northeast European Russia), D. traunsteineri is located at the northeast of its range. This species is known along the following rivers: Tsilma, Bolshaya Synya, Vym' (upper reaches), Ukhta, Aiyuva, Izhma, Schugor, Podcherem, Ilych, Pechora (upper reaches), Vychegda, Vol', Nizhnyaya Puzla, Sysola, Lokchim, and Luza. The orchid inhabits grass-Sphagnum mires, Carex-Hypnum-Sphagnum mires, and grass-Hypnum mires.

Field studies have been conducted in 2014 2019 at the Syktyvdinsk district of the Komi Republic (southern region). The investigated population is located in the River Tylayu floodplain $\left(61.59277400^{\circ} \mathrm{N}, 50.62445621^{\circ} \mathrm{E}\right)$, in a spring Menyanthes-Carex-Hypnum fen with some individual birches (Betula) $(\mathrm{pH}=7.3)$ (Fig. 1, Fig. 2).

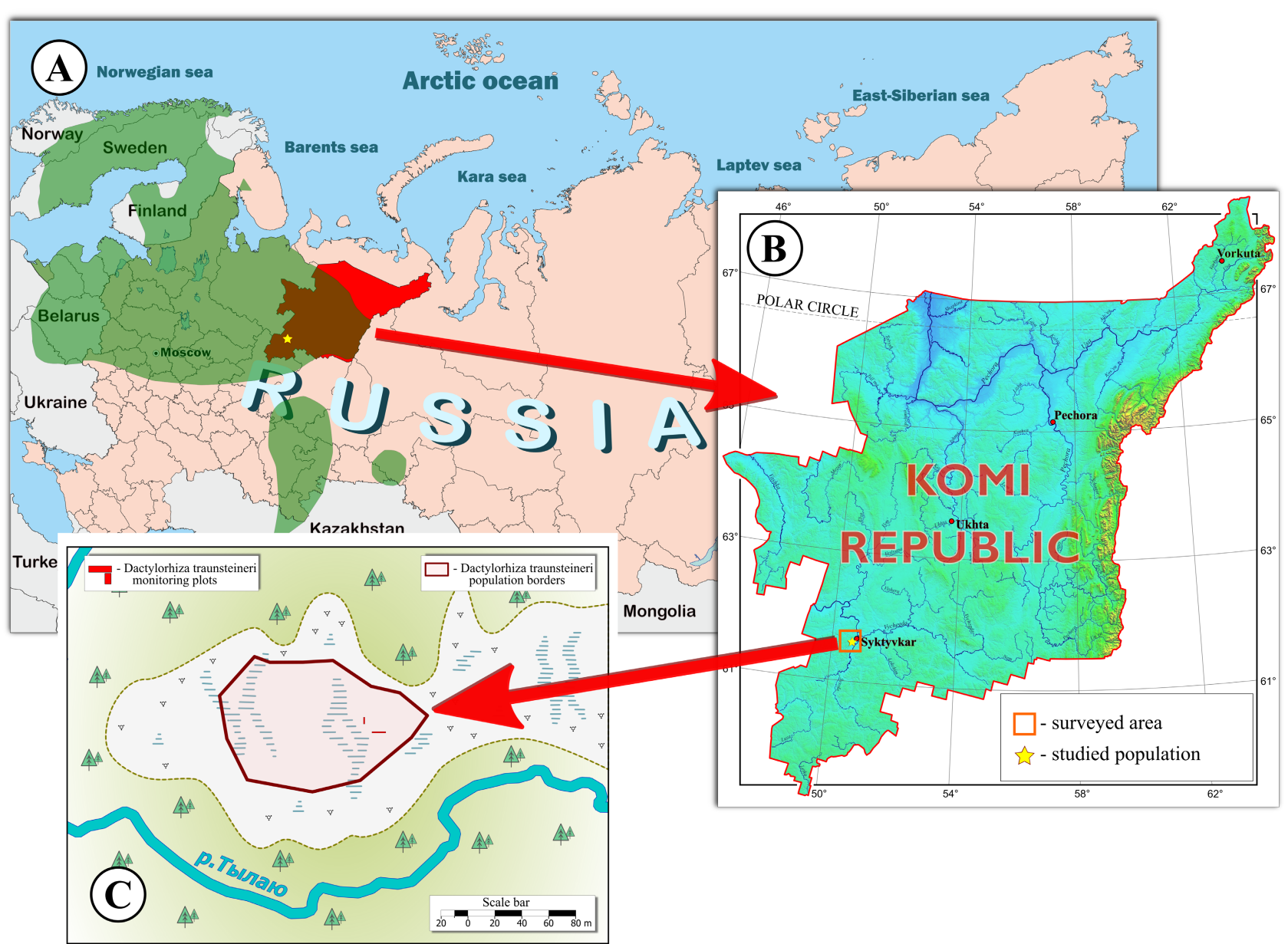

Fig. 1. Localisation of the studied Dactylorhiza traunsteineri population on the map of Russia (A) (green - the range of the species according to Kühn et al. (2019) with changes for Murmansk region according to Blinova \& Uotila (2012), Blinova (2015) and for the Komi Republic according to Kirillova \& Kirillov (unpublished data)), in the Komi Republic (B) and its borders within a fen in the River Tylayu floodplain (C). 

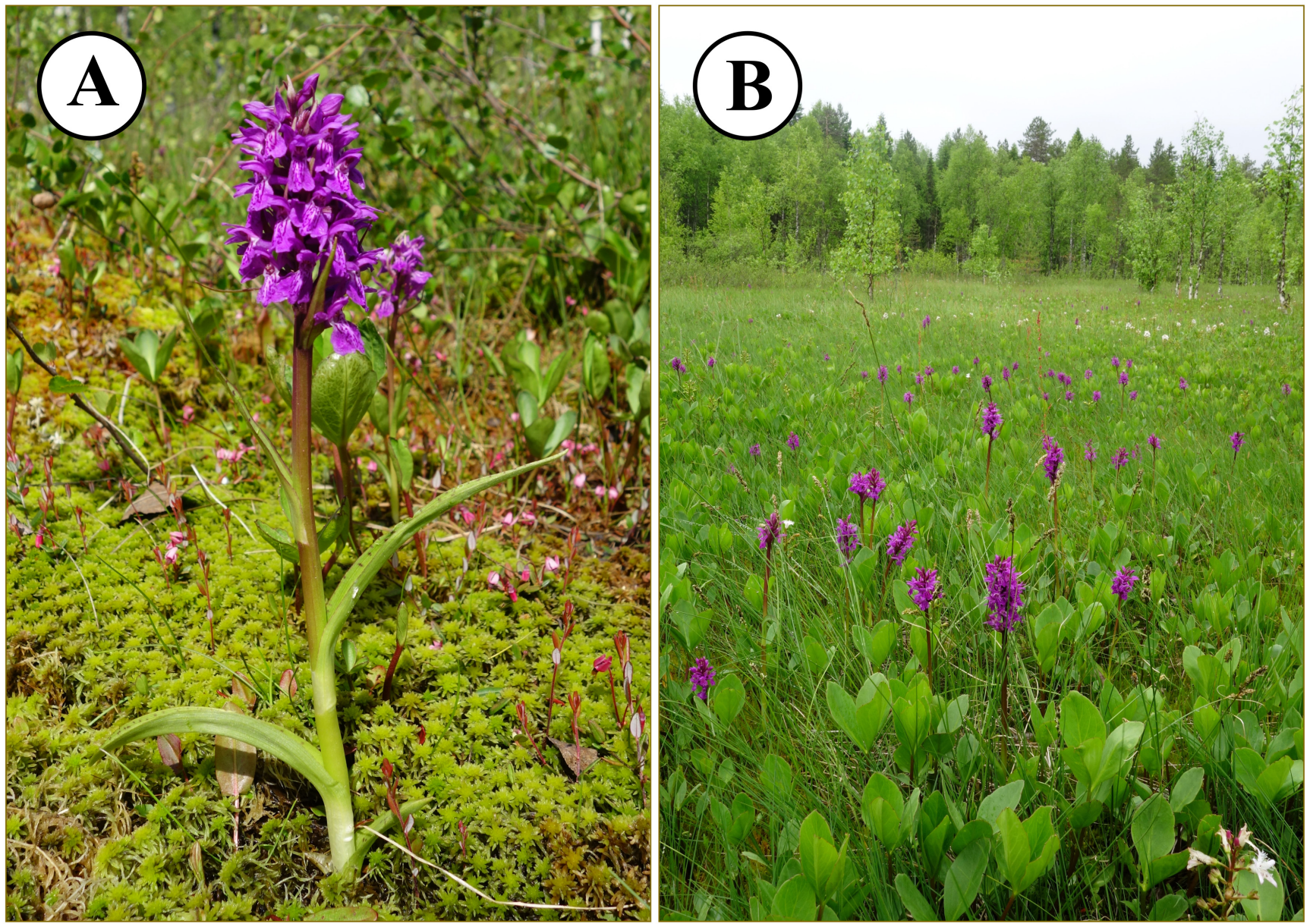

Fig. 2. Dactylorhiza traunsteineri in the Komi Republic. A - individual plant, B - a part of the studied population.

\section{Measurements of morphometric parameters of individuals}

Of 30 individuals in the field, we measured annually the plant height, inflorescence length, number and size of leaves, number of flowers and fruits (capsules). To reveal the size of flower parts in a certain individual, two flowers were mounted on cardboard from the middle part of the inflorescence using a transparent adhesive tape. Under laboratory conditions, electronic images of flowers were obtained using a scanner. Subsequently, we used them to measure their parts (lip, spur, petals) using Gimp 2.8 software.

To study seeds, we collected annually from 10 plants the fruits with matured seeds from the middle part of the inflorescence before they begin to open. Seeds were analysed using an MSP-2 light microscope $(4.5 \times$ magnification $)$ with a TS-500 digital video camera (LOMO, Russia). The measurements were performed on digital photographs using ToupView software (ToupTek, China). We estimated the average length and width of each seed and embryo and their volume (Arditti et al., 1979; Healey et al., 1980) for 40-50 seeds from samples of each study year. To determine the seed quality, we used a mixture of seeds from capsules selected from different plants within the studied population (at least 600 seeds). The seeds were examined under the MSP-2 light microscope, marking seeds with embryo and seeds without normally developed embryo. The calculation of the seed number per capsule was carried out using the method we developed to analyse digital images of orchid seeds using the ImageJ software package (Kirillova \& Kirillov, 2015, 2017a).

\section{Estimation of population structure}

To map the population, estimate its area and number of orchid individuals, we used the original method we developed on the basis of the joint use of aerial photography material (obtained using unmanned aerial vehicle DJI Phantom 2 Vision + ) and results of the field study on the orchid population.

In 2015, we established the fixed study plot (15 $\mathrm{m}^{2}$ ), where we annually indicated the location of all D. traunsteineri individuals with estimation of their ontogenetic stages. This allowed monitoring the development of each individual from appearance to dying. The determination of ontogenetic stages was conducted using widely accepted approaches taking into account specific features of orchids (Blinova, 
1998; Vakhrameeva, 2000). We determined the following ontogenetic stages: juvenile (plants with one leaf of middle formation with 2-4 veins), immature (plants with 1-2 leaves of middle formation with 6-8 veins), mature vegetative (2-3 leaves with 8-12 veins) and generative (flowering plants). We did not determine senile plants as in nature these are observed rarely because many orchids die off after the last flowering (Vakhrameeva, 2000). During 20152019 , we estimated the number of $D$. traunsteineri individuals on the study plot.

\section{Collection and calculation of weather parameters}

Data on the air temperature and precipitation amount on the study site in 2013-2019 are presented in Table 1. Characteristics of the vegetative season over the study period are described in Table 2. Values of the air temperature at the surface layer were measured using Thermochron DS1921G loggers, established near the orchid population at the height of $2 \mathrm{~m}$ above ground level. The frequency of temperature measurements was every 180 minutes. The measurement time was associated with standard synoptic periods. The precipitation amount was estimated using the open access source of «Array of urgent data on the main meteorological parameters at the stations of Russia» (http://aisori-m. meteo.ru). We used data from meteostation «Syktyvkar» (WMO ID 23804), located at $12 \mathrm{~km}$ of the study site $\left(61.67720858^{\circ} \mathrm{N}, 50.78470815^{\circ} \mathrm{E}\right)$. On the basis of the obtained meteorological data, we calculated the Selyaninov Hydrothermal Coefficient (HTC) using the following formula:

$$
H T C=\frac{R \times 10}{\sum t}, \text { where }
$$

$R$ - sum of precipitation amount ( $\mathrm{mm}$ ) over the period with temperature values $>10^{\circ} \mathrm{C}$;

$\sum t$ - sum of temperature values $\left({ }^{\circ} \mathrm{C}\right)$ over the period with temperature values $>10^{\circ} \mathrm{C}$.

\section{Statistical analysis}

Preliminary processing and analysis of data were conducted using Microsoft Office Excel 2010. Statistical analysis was processed using $\mathrm{R}$ (v.3.4.2) (The R foundation). In the main text and tables, we have indicated the arithmetic mean (M) and standard deviation (SD).

We used the Shapiro-Wilk W-test to check the samples of the values of the morphometric parameters of plant individuals, fruits and seeds for the normal distribution. To compare the samples, we used parametric methods (Student's t-test for sam- ples with normal distribution) and non-parametric methods (Wilcoxon-Mann-Whitney test for data with deviations from the normal distribution).

\section{Results}

Seasonal development of plant individuals

In the Komi Republic, the average duration of the vegetative season (with the average daily air temperature values $>5^{\circ} \mathrm{C}$ ) was 149 days (with variation of 142-170 days, between 26 April and 11 October) over the study period. The seasonal development of $D$. traunsteineri lasts from May to August (Fig. 3), while aboveground shoots die out in September. The vegetation begins often in mid-May. But sometimes this period shifts being related to different dates of vegetation period starting. For example, the earlier ( 8 April) beginning of the vegetation period in 2016 led to the fact that plants appeared earlier - in early May. The late dates of beginning of the vegetation period in 2017-2018 (11-18 May) shifted dates of D. traunsteineri's vegetation period to early June. The flowering begins at mid-June, its peak - in the third - fourth weeks of June. However, the flowering stage could also be shifted depending on the weather conditions. In 2016, plants flowered earlier, and the flowering peak was at mid-June. This was related to a very warm early summer (average air temperature of min-June was $17.8^{\circ} \mathrm{C}$ with a norm of $14^{\circ} \mathrm{C}$ ) in this vegetative season. Vice versa, in 2017 and 2018, the flowering stage was shifted to early July. In August, the fruits ripen, darken, crack, and seeds begin to spill out. At this time, the renewal bud becomes noticeable. From this bud a young shoot will be developed the next year. By autumn, both young vegetative and young generative organs of future plant will be formed in the renewal bud. In such form, the renewal bud is wintered, while in spring, a new shoot will be developed.

\section{Morphometric parameters of plant individuals}

The morphometric parameter study for $D$. traunsteineri generative individuals demonstrated that the mean plant height was $21.30 \pm 4.60 \mathrm{~cm}$ on the study site. Each plant has an average of three leaves. The bottom leaf is $7.29 \pm 1.86 \mathrm{~cm}$ long and $1.31 \pm 0.27 \mathrm{~cm}$ wide, the second leaf from the bottom is $9.0 \pm 1.49 \mathrm{~cm}$ long and $1.26 \pm 0.29 \mathrm{~cm}$ wide. The inflorescence is $5.04 \pm 1.19 \mathrm{~cm}$ long, with $14.9 \pm 4.90$ (from 6 to 29) flowers. The petal length is $10.0 \pm 1.03 \mathrm{~mm}$. The flower lip is $8.91 \pm 0.89 \mathrm{~mm}$ long and $10.62 \pm 1.35 \mathrm{~mm}$ wide. 
Table 1. Average daily air temperatures and precipitation amount obtained from May to September every ten days of each month (the format is month ten days) on the study site

\begin{tabular}{|c|c|c|c|c|c|c|c|c|c|c|c|c|c|c|c|}
\hline \multirow{2}{*}{ Year } & \multicolumn{15}{|c|}{ Average daily temperatures, ${ }^{\circ} \mathrm{C}$} \\
\hline & $05 \_\mathrm{I}$ & 05 II & 05 III & $06 \_$I & 06 II & 06 III & 07 I & 07 II & 07 III & 08 II & 08 II & 08 III & 09_I & 09_II & 09 III \\
\hline 2013 & 6.4 & 8.5 & 11.6 & 15.4 & 15.5 & 21.0 & 21.1 & 17.2 & 19.8 & 18.8 & 16.6 & 13.2 & 9.9 & 9.9 & 5.9 \\
\hline 2014 & 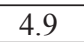 & 13.6 & 13.3 & 15.5 & 11.8 & 13.1 & 1 & 3.8 & 6 & .4 & 6.2 & 2.6 & 9.6 & 7.9 & 9.8 \\
\hline 2015 & 0 & 15.2 & 17.7 & 15.0 & 13.8 & 20.0 & 12.3 & 13.9 & 15.0 & 14.9 & 13.3 & 9.2 & 9.4 & 10.8 & 11.1 \\
\hline 2016 & 3 & 10.3 & 15.4 & 10.5 & 17.8 & 15.6 & 19.6 & 19.7 & 20.3 & 20.7 & 19.4 & 14.5 & 10.1 & 9.1 & 7.8 \\
\hline 2017 & 4.0 & 5.7 & 5.4 & 10.6 & 14.3 & 12.4 & 15.8 & 20.6 & 18.6 & 14.9 & 16.7 & 16.4 & 9.0 & 8.5 & 5.0 \\
\hline 2018 & .9 & 10.7 & 9.5 & 7.1 & 12.9 & 20.6 & 18.2 & 20.7 & 19.4 & 15.6 & 14.8 & 13.2 & 10.8 & 9.7 & 8.2 \\
\hline \multirow[t]{3}{*}{2019} & 1.4 & 11.3 & 10.2 & 13.4 & 12.2 & 15.3 & 15.7 & 15.5 & $\begin{array}{l}14.8 \\
\end{array}$ & 10.2 & 13.4 & 10.5 & 11.6 & 10.1 & 2.5 \\
\hline & \multicolumn{15}{|c|}{ Average daily precipitation amount, $\mathrm{mm}$} \\
\hline & $05 \_I$ & 05 II & 05_III & $06 \_$I & 06_II & 06_III & $07 \_$I & 07 II & 07_III & $08 \_\mathrm{I}$ & 08_II & 08 IIII & 09_I & 09_II & 09_III \\
\hline 2013 & $3 . \overline{5}$ & 22.3 & 5.0 & 15.9 & 13.0 & 16.8 & 13.0 & 6.8 & 8.8 & 4.5 & 1.7 & 21.6 & 21.2 & 3.7 & 13.2 \\
\hline 2014 & 28.5 & 0.6 & 17.4 & 10.8 & 63.1 & 30.5 & 8.3 & 9.1 & 66.8 & 26.8 & 7.7 & 48.1 & 8.1 & 18.9 & 4.2 \\
\hline 2015 & 12.8 & 1.8 & 26.6 & 21.0 & 14.6 & 19.3 & 4. & 13.3 & 25.1 & 44.4 & 31.6 & 8.4 & 20.7 & 23.1 & 26.3 \\
\hline 2016 & 59.4 & 15.0 & 95.3 & 17.8 & 6.5 & 26.3 & 18.2 & 35.9 & 16.3 & 31.3 & 81.0 & 58.7 & 6.7 & 27.5 & 22.2 \\
\hline 2017 & 6.7 & 9.6 & 36.7 & 20.5 & 43.0 & 34.1 & 14.8 & 10.6 & 53.6 & 60.9 & 15.6 & 6.7 & 9.3 & 36.1 & 31.0 \\
\hline 2018 & 6.0 & 18.4 & 27.5 & 35.6 & 30.9 & 9.4 & 46.9 & 39.8 & 0.0 & 16.2 & 24.3 & 11.4 & 11.1 & 0.6 & 19.8 \\
\hline 2019 & 82.7 & 23.7 & 28.8 & 18.8 & 13.9 & 56.7 & 64.3 & 17.6 & 2.4 & 15.2 & 10.3 & 12.0 & 11.1 & 0.6 & 19.8 \\
\hline
\end{tabular}

Table 2. Meteorological characteristics of vegetative seasons at the study site in 2014-2019

\begin{tabular}{|c|c|c|c|}
\hline Year & $\begin{array}{c}\text { Sum of temperature values }\left({ }^{\circ} \mathrm{C}\right) \text { over the period } \\
\text { with temperature values }>10^{\circ} \mathrm{C}\end{array}$ & $\begin{array}{c}\text { Precipitation amount }(\mathrm{mm}) \text { over the period } \\
\text { with temperature values }>10^{\circ} \mathrm{C}\end{array}$ & $\begin{array}{c}\text { Selyaninov Hydrothermal } \\
\text { Coefficient }(\text { HTC) }\end{array}$ \\
\hline 2014 & 1284.5 & 247.4 & 1.9 \\
\hline 2015 & 1203.0 & 168.0 & 1.4 \\
\hline 2016 & 1548.1 & 253.5 & 1.6 \\
\hline 2017 & 1355.7 & 238.5 & 1.8 \\
\hline 2018 & 1343.7 & 180.0 & 1.3 \\
\hline 2019 & 946.9 & 266.4 & 2.8 \\
\hline
\end{tabular}

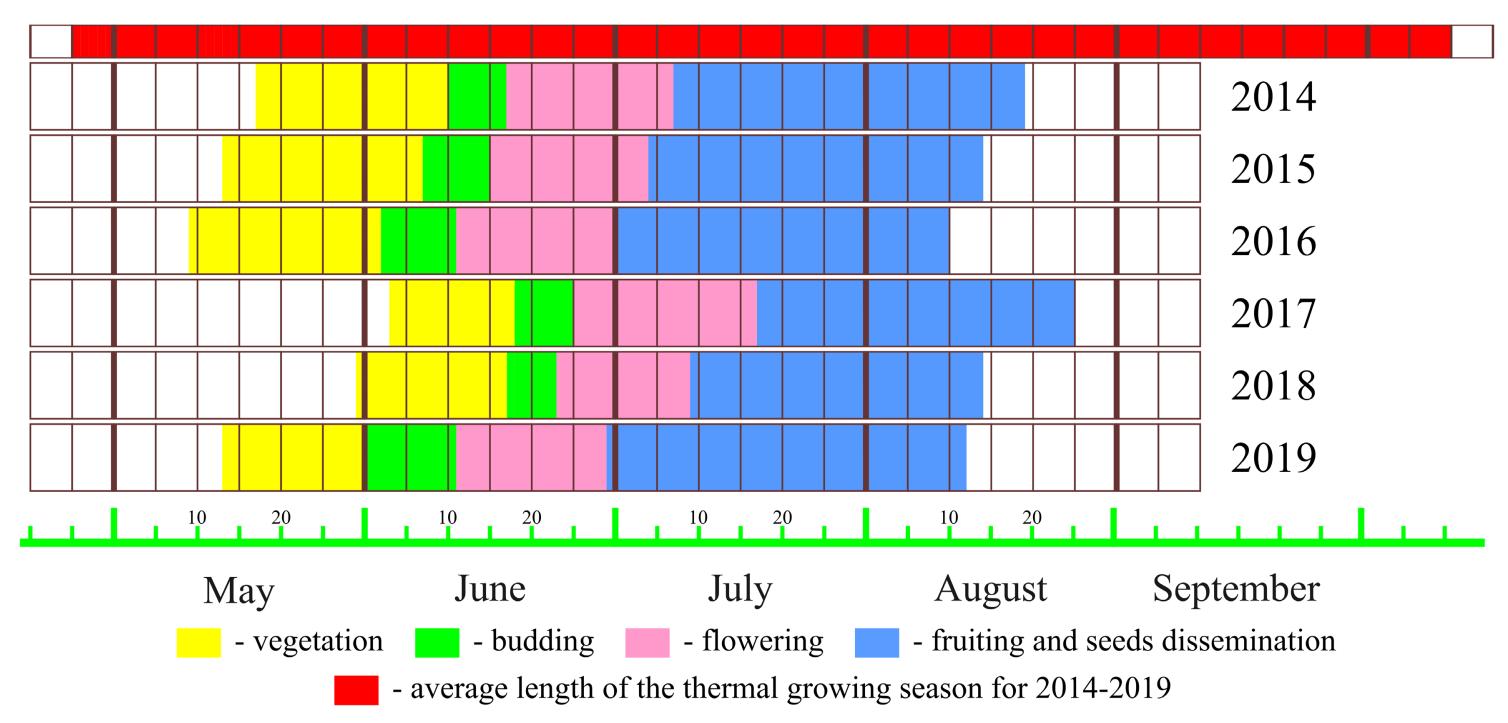

Fig. 3. Seasonal development of Dactylorhiza traunsteineri in the Komi Republic in 2014-2019 (each month is divided into six five-day periods).

Morphometric parameters of generative individuals of $D$. traunsteineri at different years are presented in Table 3. The height of the plants varied from $15.9 \mathrm{~cm}$ to $25.7 \mathrm{~cm}$. The highest value was found in 2015 , while the lowest value in 2016 . The vegetative season of 2016 was the warmest over the whole study period (Table 2). We found a positive significant correlation $(r=0.9)$ between plant height and inflorescence length. Both these parameters are negatively correlated with the precipitation amount in early May of the current year, and they are positively correlated with the air temperature values in the first half of August of the previous vegetative season (Table 4). The leaf size had maximal values in 2015 , while a minimal size of leaves was found in 2018 (Table 3). The size of the bottom leaf was positively correlated with the air temperature values early June of the current vegetative season, while the leaf length had a positive correlation with the precipitation amount in August of the previous vegetative season (Table 4). 
Table 3. Morphometric parameters of Dactylorhiza traunsteineri individuals in the studied population in 2014-2019

\begin{tabular}{|c|c|c|c|c|c|c|}
\hline Parameter $\quad$ Year & 2014 & 2015 & 2016 & 2017 & 2018 & 2019 \\
\hline Plant height, $\mathrm{cm}$ & $23.20 \pm 3.07$ & $25.66 \pm 3.52 * *$ & $15.87 \pm 1.97 * *$ & $23.92 \pm 3.89 * *$ & $21.22 \pm 3.01 * *$ & $18.33 \pm 3.36^{* *}$ \\
\hline Inflorescence length, cm & $5.48 \pm 1.49$ & $5.85 \pm 1.33$ & $4.33 \pm 0.60^{* *}$ & $5.19 \pm 1.04 * *$ & $4.76 \pm 0.90$ & $4.68 \pm 0.95$ \\
\hline Number of leaves, units & $3.0 \pm 0.26$ & $3.0 \pm 0.46$ & $3.0 \pm 0.52$ & $2.90 \pm 0.31$ & $2.97 \pm 0.18$ & $3.17 \pm 0.38^{*}$ \\
\hline First leaf length, cm & $6.66 \pm 1.76$ & $8.27 \pm 1.78 * *$ & $7.09 \pm 1.29 * *$ & $7.87 \pm 2.03$ & $6.60 \pm 1.41 * *$ & $7.30 \pm 2.23$ \\
\hline First leaf width, cm & $1.32 \pm 0.30$ & $1.43 \pm 0.26$ & $1.33 \pm 0.29$ & $1.33 \pm 0.25$ & $1.16 \pm 0.23 *$ & $1.29 \pm 0.24^{*}$ \\
\hline Second leaf length, cm & $8.87 \pm 1.03$ & $9.57 \pm 1.18^{*}$ & $8.55 \pm 1.42 * *$ & $9.41 \pm 1.33^{*}$ & $8.30 \pm 1.76^{* *}$ & $9.35 \pm 1.73^{*}$ \\
\hline Second leaf width, $\mathrm{cm}$ & $1.31 \pm 0.30$ & $1.34 \pm 0.32$ & $1.38 \pm 0.30$ & $1.24 \pm 0.20$ & $1.09 \pm 0.21 * *$ & $1.23 \pm 0.32$ \\
\hline Number of flowers, units & $15.47 \pm 4.88$ & $16.03 \pm 4.59$ & $11.27 \pm 3.03 * *$ & $15.13 \pm 4.60 * *$ & $14.33 \pm 4.49$ & $17.2 \pm 5.65^{*}$ \\
\hline Lip length, mm & $8.74 \pm 0.63$ & $8.46 \pm 0.76$ & $9.39 \pm 1.06^{* *}$ & $9.18 \pm 0.81$ & $9.20 \pm 0.82$ & $8.47 \pm 0.84 * *$ \\
\hline Lip width, mm & $10.36 \pm 1.29$ & $9.65 \pm 0.87 *$ & $11.56 \pm 0.96^{* *}$ & $10.83 \pm 1.34^{*}$ & $11.37 \pm 1.42$ & $9.94 \pm 1.05^{* *}$ \\
\hline Upper petal length, mm & $9.84 \pm 0.89$ & $9.36 \pm 0.73 *$ & $10.79 \pm 1.09^{* *}$ & $10.26 \pm 0.76^{*}$ & $10.18 \pm 0.84$ & $9.41 \pm 0.92 * *$ \\
\hline Bottom petal length, mm & $10.24 \pm 0.80$ & $9.82 \pm 0.79 *$ & $11.41 \pm 1.10^{* *}$ & $10.79 \pm 0.93 *$ & $10.96 \pm 0.81$ & $9.89 \pm 0.80 * *$ \\
\hline Spur length, $\mathrm{mm}$ & $7.54 \pm 0.97$ & $6.93 \pm 1.01 *$ & $7.83 \pm 1.10^{* *}$ & $7.61 \pm 0.87$ & $8.43 \pm 0.86^{* *}$ & $7.06 \pm 1.07 * *$ \\
\hline Spur width, mm & $3.22 \pm 0.49$ & $2.90 \pm 0.32 * *$ & $3.61 \pm 0.42 * *$ & $3.25 \pm 0.41 * *$ & $3.52 \pm 0.44^{*}$ & $2.80 \pm 0.38 * *$ \\
\hline Bract length, mm & $18.66 \pm 2.48$ & $19.03 \pm 2.44$ & $20.41 \pm 2.60 * *$ & $20.93 \pm 2.51$ & $21.62 \pm 3.13$ & $21.18 \pm 3.09$ \\
\hline Ovary length, mm & $10.06 \pm 1.26$ & $9.36 \pm 1.01 *$ & $10.89 \pm 0.84 * *$ & $9.71 \pm 1.33 * *$ & $10.39 \pm 1.01 *$ & $8.97 \pm 1.24 * *$ \\
\hline Fruit length, $\mathrm{mm}$ & $11.78 \pm 1.15$ & $11.03 \pm 0.80^{*}$ & $11.60 \pm 1.29$ & $12.37 \pm 1.25^{*}$ & $12.94 \pm 1.08$ & $12.26 \pm 1.27$ \\
\hline Fruit width, mm & $3.89 \pm 0.50$ & $3.44 \pm 0.54 *$ & $4.30 \pm 0.59 * *$ & $4.38 \pm 0.53$ & $4.50 \pm 0.50$ & $4.77 \pm 0.62$ \\
\hline Seed length, mm & $0.61 \pm 0.08$ & $0.64 \pm 0.08$ & $0.75 \pm 0.08^{* *}$ & $0.73 \pm 0.08$ & $0.78 \pm 0.09 * *$ & $0.74 \pm 0.10^{*}$ \\
\hline Seed width, mm & $0.20 \pm 0.04$ & $0.19 \pm 0.03^{*}$ & $0.21 \pm 0.03^{* *}$ & $0.21 \pm 0.04$ & $0.20 \pm 0.03^{*}$ & $0.22 \pm 0.03^{* *}$ \\
\hline Seed volume $\times 10^{-3}, \mathrm{~mm}^{3}$ & $6.96 \pm 0.01$ & $6.01 \pm 0.01$ & $8.29 \pm 0.01 * *$ & $9.02 \pm 0.01$ & $7.93 \pm 0.01$ & $9.19 \pm 0.01 *$ \\
\hline Embryo length, mm & $0.24 \pm 0.03$ & $0.20 \pm 0.02 * *$ & $0.24 \pm 0.02 * *$ & $0.23 \pm 0.03$ & $0.24 \pm 0.03$ & $0.24 \pm 0.03$ \\
\hline Embryo width, $\mathrm{mm}$ & $0.14 \pm 0.02$ & $0.12 \pm 0.01 * *$ & $0.15 \pm 0.02 * *$ & $0.15 \pm 0.02$ & $0.15 \pm 0.01$ & $0.15 \pm 0.02$ \\
\hline Embryo volume $\times 10^{-3}, \mathrm{~mm}^{3}$ & $2.68 \pm 0.01$ & $1.59 \pm 0.01 * *$ & $2.82 \pm 0.01 * *$ & $2.78 \pm 0.01$ & $2.74 \pm 0.01$ & $2.85 \pm 0.01$ \\
\hline Proportion of seeds without embryo, \% & 12.3 & 1.9 & 3.8 & 8.3 & 5.9 & 8.4 \\
\hline
\end{tabular}

Note: ${ }^{*}-p<0.05, * *-p<0.01$.

Table 4. Correlation between weather parameters (air temperature and precipitation amount) and morphometric parameters of the Dactylorhiza traunsteineri individuals in the studied population

\begin{tabular}{|c|c|c|c|c|}
\hline \multirow{2}{*}{$\begin{array}{l}\text { Morphometric } \\
\text { parameters }\end{array}$} & \multicolumn{2}{|c|}{ Air temperature (in format «month_10 days») } & \multicolumn{2}{|c|}{ Precipitation amount (in format «month_10 days») } \\
\hline & $\begin{array}{c}\text { Previous vegetative } \\
\text { period }\end{array}$ & $\begin{array}{l}\text { Current vegetative } \\
\text { period }\end{array}$ & $\begin{array}{c}\text { Previous vegetative } \\
\text { period }\end{array}$ & $\begin{array}{l}\text { Current vegetative } \\
\text { period }\end{array}$ \\
\hline Plant height & $+\mathbf{0 8} \_$I,,$+08 \_$II & - & +08 III & $-05 \_$I \\
\hline Inflorescence length & $+08 \_I$ & - & - & $-05 \_$II \\
\hline First leaf length & - & - & +08_III & - \\
\hline First leaf width & - & $+06 \_$I & - & - \\
\hline Second leaf length & - & - & +08 III & - \\
\hline Second leaf width & -08_III & - & - & - \\
\hline Number of flowers & - & - & - & -05 III \\
\hline Lip length & - & +07_I, +07_II & - & - \\
\hline Lip width & - & +07_I, +07_II & +09_III & - \\
\hline Upper petal length & - & +07 I & - & +05 III \\
\hline Bottom petal length & - & +07_I, +07_II & - & - \\
\hline Spur width & - & +07 I & - & - \\
\hline Bract length & - & - & +09_III & +05 II \\
\hline Fruit width & - & - & - & $+07 \_I$ \\
\hline Fruit set & - & $-06 \_$III & - & +06 III \\
\hline Embryo volume & - & +07 I & - & - \\
\hline Proportion of seeds without embryo & - & - & - & +06 II \\
\hline Number of juvenile individuals & +08 I & - & +08 III & - \\
\hline Number of generative individuals & $+08 \_I$ & - & $+08 \_$III & - \\
\hline Number of plants & - & $-05 \_I$ & +06_III, +09_II & $-05 \_I$ \\
\hline Real seed production per individual & - & - & - & +06_III \\
\hline
\end{tabular}

Note: The table shows the periods, in which we found a statistically significant correlation of the studied morphometric parameters with weather conditions (periods with $p<0.05$ are in bold, other $-p<0.10$ ). 
Depending on the study year, the number of flowers varied from 11.3 (in 2016) to 17.2 (in 2019). The flower size varied over the years, too (Table 3). This parameter was correlated positively with the sum of active temperature values $\left(>10^{\circ} \mathrm{C}\right)$ in the whole vegetative season $(\mathrm{r}=0.9)$ and with the air temperature in July of the current year (Table 4). The largest flowers were found in the warmest year, 2016, when we noted the maximal sum of active temperature values $\left(1548.1^{\circ} \mathrm{C}\right)$, while minimal values were noted in the coldest vegetative season, 2019, $\left(946.9^{\circ} \mathrm{C}\right)($ Table 2$)$. The flower size was negatively significantly correlated with the number of flowers $(r=-0.9)$.

\section{Structure and dynamics of population}

In the studied population, the total D. traunsteineri abundance was 23722 plants at an area of $11302 \mathrm{~m}^{2}$. In the study plot, the number of individuals increased slightly in 2017 (Fig. 4) after the warmest and sufficiently humid year of 2016. This parameter sharply decreased in 2019, i.e. after the driest vegetative season of 2018, when we found the minimal value of HTC (Table 2). The number of individuals was positively correlated with the precipitation amount in late June and the second decade of September of the previous vegetative season (Table 4), while this parameter was negatively correlated with HTC of the previous vegetative season $(r=-0.9)$.

Over all study years, the age structure of the D. traunsteineri population contained individuals of all ontogenetic stages with a maximum of mature vegetative individuals (Fig. 4). The highest number of generative individuals was found in 2015 and 2017, while the lowest number of flowering plants was registered in 2016. The number of generative individuals was positively correlated with the air temperature and precipitation amount in August of the previous vegetative season (Table 4), as well as with the precipitation amount over the period with an air temperature $>10^{\circ} \mathrm{C}$ in the previous vegetative season $(r=0.9)$.

In $2015,7.7 \%$ of the flowering plants were damaged. This was probably influenced by frosts in October of the previous year (air temperature of the second decade of October was $-5^{\circ} \mathrm{C}$ ). In this period, frosts are harmful to the future generative plants because in autumn flower primordia have already been formed in buds, from which the next year inflorescences will develop.

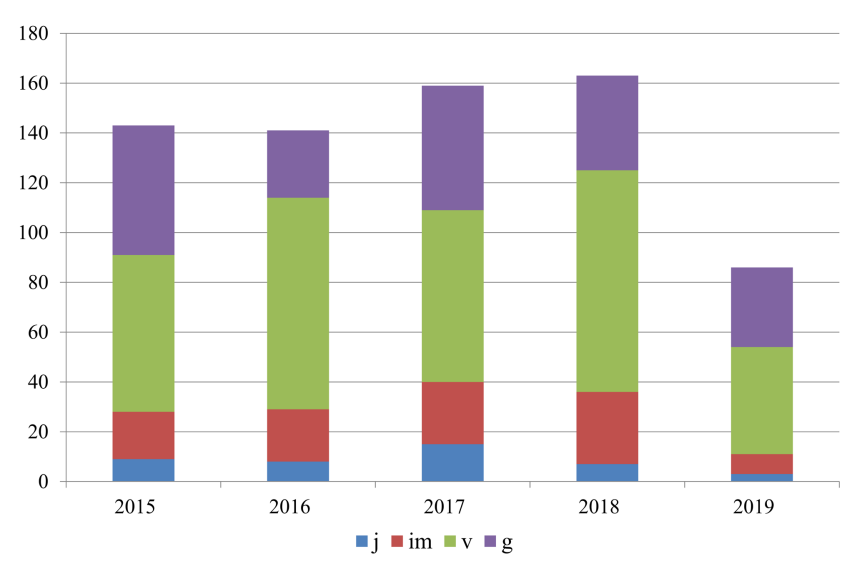

Fig. 4. Number of Dactylorhiza traunsteineri individuals in the study plot. X-axis - study years, Y-axis - number of individuals of different ontogenetic stages: $\mathrm{j}$ - juvenile, im - immature, $\mathrm{v}$ - mature vegetative, $\mathrm{g}$-generative.

The observation of the mapped orchids showed that $57 \%$ of the generative individuals flowered only one time, $37 \%$ of the plants - during only two subsequent years, and only $6 \%$ individuals flowered over three years. The next year after flowering, most of the individuals (64\%) turned into the temporarily non-blooming stage, which lasted 1-2 years. Sometimes after a year spent in a mature vegetative stage, the plants bloomed again. In addition, $36 \%$ of the generative plants died after flowering.

\section{Reproductive biology}

Over six study years, the average fruit set of D. traunsteineri was $50.4 \%$. Its highest values (more than 62\%) were found in 2017 and 2019, while the lowest values $(37.5-39.0 \%)$ were recorded in 2015 and 2018 (Fig. 5). The number of the formed fruits correlated with the weather conditions in June (the time of $D$. traunsteineri flowering). This parameter was negatively correlated with the air temperature and positively correlated with the precipitation amount over this period. The fruit set does not depend on the number of flowers per inflorescence or flower size.

The seeds of $D$. traunsteineri are light brown. Mature seeds are composed of a transparent seed coat and an undifferentiated germ (Fig. 6). We found some singular seeds with two embryos. In the studied population, the average seed length was $0.71 \pm 0.10(0.41-0.93) \mathrm{mm}$, seed width $0.20 \pm 0.04(0.13-0.32) \mathrm{mm}$. The seed index was 3.6. The embryo size was $0.22 \pm 0.03 \mathrm{~mm}$ long and $0.14 \pm 0.02 \mathrm{~mm}$ wide. On average, $67.5 \%$ of a seed is occupied by an empty airspace.

The seed volume was positively correlated with the embryo volume $(r=0.9)$ and the fruit set 
$(\mathrm{r}=0.8)$. In the years characterised by a low fruit set $(2014,2015,2018)$, we found the lowest size of seeds (Table 3 ). The embryo volume was positively correlated with the air temperature in early July, i.e. a period when fruits are being formed.

The fruit of $D$. traunsteineri is a capsule. In the Komi Republic, its average size is $12.0 \pm 1.28 \times 4.23 \pm 0.65 \mathrm{~mm}$. The highest size of fruits was registered in 2018 and 2019, while minimal values were found in 2015 (Table 3). One capsule of $D$. traunsteineri contains on average $4090 \pm 145$ seeds (minimum - 2352 seeds, maximum -5197 seeds). The highest average seed number (4300) was found in 2016 and 2019, the lowest average value (3700) - in 2015 (Table 5). We found a positive correlation between the seed number and the fruit width $(\mathrm{r}=0.8)$.

Some proportion of seeds does not contain a normally developed embryo (Fig. 6b, Table 3). These seeds have a lower size $-0.42 \times 0.10 \mathrm{~mm}$, i.e. they are almost two-fold smaller than seeds with an embryo. The proportion of seeds without an embryo was positively correlated with the precipitation amount in June. The highest number of seeds without an embryo was found in 2014, when we registered a maximal precipitation amount in mid-June $-63 \mathrm{~mm}$, that is two-fold higher than the norm $(26 \mathrm{~mm})$.

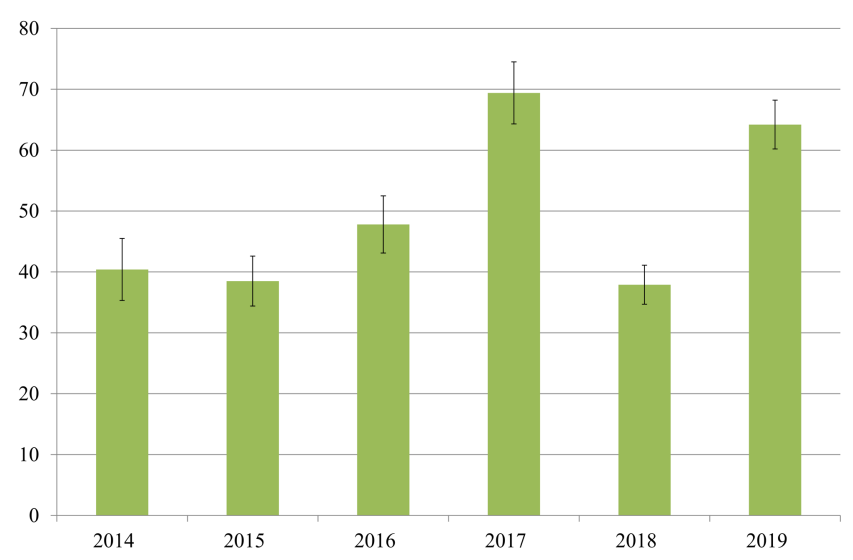

Fig. 5. Fruit set of Dactylorhiza traunsteineri in the studied population in 2014-2019. X-axis - study years, Y-axis - fruit set, \%.
In different years, the conditionally potential seed production of generative plants (seed production with $100 \%$ pollination efficiency) varied from 48800 seeds to 75300 seeds per individual. The conditionally real seed production (where pollination efficiency is taken into account) varied from 22000 seeds to 46800 seeds per plant (Table 5). Over five study years, the average real seed production was 29487 seeds. The maximum average value (42 884 seeds) was found in 2019, while the minimal average value (20 960 seeds) was registered in 2018. The real seed production was positively correlated with HTC $(r=0.9)$, which indicates the level of water content in an area, as well as the precipitation amount in late June.

We calculated the seed yield by multiplication the real seed production on the average number of generative plants per $1 \mathrm{~m}^{2}$. The number of generative plants per $1 \mathrm{~m}^{2}$ varied in different study years with a variation from 2.6 individuals per 1 $\mathrm{m}^{2}$ (in 2016) to 5.4 individuals per $1 \mathrm{~m}^{2}$ (in 2017). The maximal seed yield was found in 2017 with 199100 seeds per $1 \mathrm{~m}^{2}$, while a minimal value (61 600 seeds per $1 \mathrm{~m}^{2}$ ) - in 2016. The seed yield was positively significantly correlated with the sum of active temperature values of the previous vegetative season $(r=0.9)$.

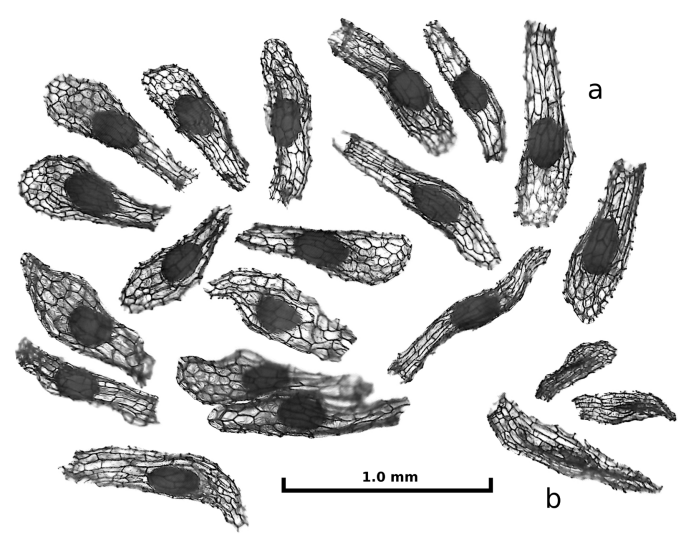

Fig. 6. Seeds with (a) and without (b) embryo of Dactylorhiza traunsteineri in the studied population.

Table 5. Seed production of Dactylorhiza traunsteineri individuals in the studied population in 2015-2019

\begin{tabular}{|c|c|c|c|c|c|c|}
\hline \multicolumn{2}{|c|}{\begin{tabular}{|lc} 
& Year \\
Parameter
\end{tabular}} & 2015 & 2016 & 2017 & 2018 & 2019 \\
\hline \multirow{3}{*}{ Seed number per fruit, units } & mean & 3752 & 4330 & 3846 & 4145 & 4376 \\
\hline & $\min$ & 3071 & 3409 & 2352 & 2469 & 3056 \\
\hline & $\max$ & 4761 & 5154 & 5197 & 4889 & 4975 \\
\hline \multicolumn{2}{|c|}{ Average number of the seeds with embryo per fruit, units } & 3681 & 4165 & 3527 & 3900 & 4008 \\
\hline \multicolumn{2}{|c|}{ Conditionally potential seed production, units } & 60145 & 48799 & 58190 & 59398 & 75267 \\
\hline \multicolumn{2}{|c|}{ Conditionally real seed production, units } & 23456 & 24644 & 40209 & 22274 & 46816 \\
\hline \multicolumn{2}{|l|}{ Real seed production, units } & 23011 & 23707 & 36872 & 20960 & 42884 \\
\hline \multicolumn{2}{|l|}{ Seed yield, seeds $/ \mathrm{m}^{2}$} & 121957 & 61638 & 199108 & 88032 & 145804 \\
\hline
\end{tabular}


Although D. traunsteineri individuals form a large number of seeds, only a small part of them could germinate. Over all study years, the proportion of young plants was 3.5-9.4\%. Its maximal value was found in 2017 after the warmest and sufficiently humid season of 2016, when the highest number of plants in the population was observed. The minimal number of juvenile individuals was noted in 2019 after the driest season of 2018 (HTC had a minimal value, see Table 2). The number of young individuals was positively significantly correlated with the precipitation amount and the air temperature in August of the previous vegetative season (Table 4), as well as with the seed yield in the previous year $(r=0.9)$.

\section{Discussion}

Numerous investigations covering different organisms, demonstrate that changes in parameters of their life activity are associated with climate changes, such as temperature and precipitation. It was repeatedly reported that climatic factors affect the size, flowering likelihood, reproductive success, population dynamics, and survival of orchids (Blinova, 2008; Inghe \& Tamm, 1988; Wells \& Cox, 1991; Wells et al., 1998; Carey \& Farrell, 2002; Pfeifer et al., 2006; Jacquemyn et al., 2009). Our results have also demonstrated that weather conditions influence features of small and big life cycles of D. traunsteineri at the northeastern limit of its range. So, the plant size is affected by weather conditions of both current and previous vegetative seasons. A warm beginning of the vegetative season positively impacts the leaf width. The air temperature in early July is important for forming the large flowers, like Øien \& Pedersen (2003) showed that the aboveground biomass of the flowering $D$. traunsteineri individuals increases during the whole flowering period. The air temperature and the precipitation amount in August of the previous vegetative season influence positively the height of plants and the inflorescence length. Moreover, the precipitation in late August of the previous year is positively correlated with the size of future leaves of the orchid individuals. This could be explained by the fact that in this period, the organs of the future shoots are actively forming in the bud, which requires a stock of nutrients. During this period, the biomass of new tubers actively increases even after the photosynthetic assimilation ceases. This occurs due to mycotrophic activity and re-location of nutrients from aboveground shoots (Øien \& Pedersen, 2003), while positive temperature and sufficient humidity favourably affect the activity of the mycotrophic component. We noted the negative correlation between the number of flowers and their size. Thus, the plant spends resources either on the formation of a lower number of the larger flowers or a higher number of smaller flowers.

The proportion of generative individuals changed two times over the study period (from $19 \%$ to $37 \%$ ). The considerable inter-annual fluctuations in the number of flowering orchid individuals has been demonstrated also by other studies (Tamm, 1972; Øien \& Moen, 2002; Jacquemyn et al., 2007; Pfeifer et al., 2006; Hutchings, 2010; Van der Meer et al., 2016). The number of flowering individuals was positively correlated with both the temperature and precipitation in August of the previous vegetative season. In Central Norway, Øien \& Moen (2002) also found a positive significant correlation between the density of generative $D$. traunsteineri individuals and the temperature of the previous vegetative season. This is associated with the fact that the flower primordia of this species are being formed a year before flowering (Øien \& Pedersen, 2003).

The number of orchid individuals in the studied population (about 23700 plants) is high for this species. So, in Central Norway, $D$. traunsteineri populations contain 400-500 flowering plants (Øien \& Moen, 2002; Øien et al., 2008; Sletvold et al., 2010b), compared to about 50 individuals in the Murmansk region of Russia (Blinova \& Uotila, 2012). A high moisture level in the current vegetative season negatively affects the size of the examined population. A similar pattern was noted for another orchid species, Neottia ovata (L.) Bluff \& Fingerh., in the Murmansk region (Blinova, 2008). However, a warm and relatively humid previous vegetative season positively affects the number of individuals in a population.

The fruit set of $D$. traunsteineri is relatively high $-50.4 \%$. In Central Norway and the Murmansk region (Russia), this parameter value does not exceed 30\% (Sletvold et al., 2010a; Blinova \& Uotila, 2012). In the Moscow region (Russia), the fruit set is $10-15 \%$ with an increase up to $60-65 \%$ in the most favourable years (Vakhrameeva et al., 2014). The number of formed fruits depends on the weather conditions during the flowering stage. At the same time, hot and dry weather negatively 
influences the fruit set of $D$. traunsteineri. This is probably explained by the fact that Bombus species are pollinators of $D$. traunsteineri (Sletvold et al., 2010b). These insects can fly already at $10^{\circ} \mathrm{C}$ and pollinate flowers even in a cold and rainy season (Jakubska-Busse \& Kadej, 2011), while their activity is decreased at a temperature $>23^{\circ} \mathrm{C}$ (Demidova, 2012). In addition, we repeatedly observed ants on $D$. traunsteineri flowers in the studied population. Perhaps, these insects also play a certain role in $D$. traunsteineri's pollination, as ants were noted as effective pollinators for some plant (including orchids) species (Rostás \& Tautz, 2010; Schiestl \& Glaser, 2012).

The fruits of $D$. traunsteineri contain a large number of small seeds. The seed number was positively correlated with the fruit width, the volume of seeds and embryos. On average, each D. traunsteineri capsule contains 4090 seeds. This value is higher than it was found for other Dactylorhiza species in the Komi Republic. For example, a Dactylorhiza fuchsii (Druce) Soó capsule contains on average of 2597 seeds (Kirillova \& Kirillov, 2013), a D. maculata (L.) Soó fruit 2835 seeds (Kirillova \& Kirillov, 2017b). In the Murmansk region (Russia), only 1200 D. traunsteineri seeds per capsule were noted (Blinova \& Uotila, 2012). The real seed production was positively correlated with the water content of the whole vegetative season and the precipitation amount during flowering of the plants.

The result of a successful reproductive process is the number of emerged and established young plants. Over all study years, this parameter was on average $5.8 \%$. A low number of juvenile individuals in $D$. traunsteineri populations was also noted by Blinova \& Uotila (2012). Øien et al. (2008) demonstrated that seeds of this species are short-living (less than one year). They do not form a seedbank in the soil, and the natural germination is very low, only $11 \%$. Therefore, seeds die, if the conditions are not favourable for germination. In addition, the contact of a seed with the mycelium of a compatible fungal symbiont is necessary for a successful development of the orchid seedling. The number of young $D$. traunsteineri individuals was positively correlated with the seed yield of the previous year, as well as with the precipitation amount and the August temperature of the previous vegetative season. The importance of moisture at the time of seed dispersal to the ground was also indicated for other orchid species $(\mathrm{Ku}-$ likov \& Filippov, 2001; Scott \& Carey, 2002).

\section{Conclusions}

The monitoring studies of the threatened orchid Dactylorhiza traunsteineri in the Komi Republic have demonstrated that its seasonal development lasts from May to August. The passage of phenophases depends on the timing of the vegetative season onset. The plant size of this species is affected by weather conditions of both current and previous vegetative seasons. It concerns especially August of the previous year when the formation of both renewal buds and primordia of future organs occurs. The number of generative individuals per population was also positively correlated with temperature and humidity in August of the previous vegetative season. The fruit set of $D$. traunsteineri is high $(50.4 \%)$. This parameter was negatively correlated with the temperature during the flowering stage and negative correlated with the precipitation amount. The seed number per capsule of $D$. traunsteineri (on average 4090 seeds) was higher than it was noted for other Dactylorhiza species in the Komi Republic. The real seed production is associated with the water content of the current vegetative season. The seed yield is high - from 88000 to 199000 seeds per $1 \mathrm{~m}^{2}$ in different study years. The number of young plants is a final indicator of the reproductive success of a plant species. This parameter was positively correlated with the precipitation amount and the temperature in August, as well as with the seed yield of the previous vegetative season. The proportion of juvenile individuals was small (from $3.5 \%$ to $9.4 \%$ in different study years). But juvenile plants were present in the population structure each year. This indicates a successful seed reproduction. In case of such a large population, a low number of $D$. traunsteineri young plants is not crucial for its status.

\section{Acknowledgements}

The study was conducted in framework of the state assignment №AAAA-A19-119011790022-1.

\section{References}

Arditti J., Michaud J.D., Healey P.L. 1979. Morphometry of orchid seeds. I. Paphiopedilum and native California and related species of Cypripedium. American Journal of Botany 66(10): 1128-1137. DOI: 10.1002/j.15372197.1979.tb06332.x

Blinova I.V. 1998. Specific features of the ontogeny in some root-tuber orchids (Orchidaceae) in the extreme North. Botanicheskii Zhurnal 83(1): 85-94. [In Russian] 
Blinova I.V. 2008. Populations of orchids at the northern limit of their distribution (Murmansk Oblast): Effect of climate. Russian Journal of Ecology 39: 28-35. DOI: 10.1134/S1067413608010050

Blinova I.V. 2009. Number of individuals and dynamics of orchid populations at the northern limit of their distribution in Europe. Botanicheskii Zhurnal 94(2): 212-240. [In Russian]

Blinova I.V. 2015. Base-Rich fens in the southern part of Murmansk Region and the case for their protection. Herald of the Kola Scientific Centre of RAS 3(22): 102 114. [In Russian]

Blinova I.V., Uotila P. 2012. Dactylorhiza traunsteineri (Orchidaceae) in Murmansk Region (Russia). Memoranda Societatis pro Fauna et Flora Fennica 88: 67-79.

Brzosko E. 2002. Dynamics of island populations of Cypripedium calceolus in the Biebrza river valley (north-east Poland). Botanical Journal of the Linnean Society 139(1): 67-77. DOI: 10.1046/j.10958339.2002.00049.x

Brzosko E. 2003. The dynamics of island populations of Platanthera bifolia in the Biebrza National Park (NE Poland). Annales Botanici Fennici 40: 243-253.

Carey P.D., Farrell L. 2002. Himantoglossum hircinum (L.) Sprengel. Journal of Ecology 90(1): 206-218. DOI: 10.1046/j.0022-0477.2001.00640.x

Christenhusz M.J.M., Byng J.W. 2016. The number of known plants species in the world and its annual increase. Phytotaxa 261(3): 201-217. DOI: 10.11646/ phytotaxa.261.3.1

Cribb P.J., Kell S.P., Dixon K.W., Barrett R.L. 2003. Orchid conservation: a global perspective. In: K.W. Dixon, S.P. Kell, R.L. Barrett, P.J. Cribb (Eds.): Orchid conservation. Kota Kinabalu: Natural History Publications. P. 1-24.

Demidova A.T. 2012. Ecology and species diversity of bumblebees (Hymenoptera, Apidae, Bombini) of the middle Siberian lowland. PhD Thesis Abstract. Barnaul. 21 p. [In Russian]

Dibble A.C., Gawler S.C., Wright W.A., Vitt P., Cameron D.S., Bajcz A.W., Campbell C.S. 2019. Demography of the Rare Orchid, Isotria medeoloides (Orchidaceae) and Its Response to a Canopy Thinning Treatment. Rhodora 121(986): 67-107. DOI: 10.3119/17-19

Fay M.F. 2018. Orchid conservation: how can we meet the challenges in the twenty-first century? Botanical Studies 59(1): 1-16. DOI: 10.1186/s40529-018-0232-z

Healey P.L., Michaud J.D., Arditti J. 1980. Morphometry of Orchid Seeds. III. Native Claifornia and Related Species of Goodyera, Piperia, Platanthera and Spiranthes. American Journal of Botany 67(4): 508-518. DOI: 10.1002/j.1537-2197.1980.tb07678.x

Hutchings M.J. 2010. The population biology of the early spider orchid Ophrys sphegodes Mill. III. Demography over three decades. Journal of Ecology 98(4): 867-878. DOI: $10.1111 / \mathrm{j} .1365-2745.2010 .01661 . x$

Inghe O., Tamm C.O. 1988. Survival and flowering of perennial herbs. V. Patterns of flowering. Oikos 51(2): 203-219. DOI: $10.2307 / 3565644$
Jacquemyn H., Brys R., Hermy M., Willems J.H. 2007. Longterm dynamics and population viability in one of the last populations of the endangered Spiranthes spiralis (Orchidaceae) in the Netherlands. Biological Conservation 134(1): 14-21. DOI: 10.1016/j.biocon.2006.07.016

Jacquemyn H., Brys R., Honnay O. 2009. Large population sizes mitigate negative effects of variable weather conditions on fruit set in two spring woodland orchids. Biology Letters 5(4): 495-498. DOI: 10.1098/rsbl.2009.0262

Jakubska-Busse A., Kadej M. 2011. The pollination of Epipactis Zinn, 1757 (Orchidaceae) species in Central Europe - the significance of chemical attractants, floral morphology and concomitant insects. Acta Societatis Botanicorum Poloniae 80(1): 4957. DOI: 10.5586/asbp.2011.007

Kirillova I.A., Kirillov D.V. 2013. The biological features, reproduction, and population structure of Dactylorhiza fuchsii s. 1. (Orchidaceae) on the northern border of its range. Botanicheskii Zhurnal 98(2): 75-90. [In Russian]

Kirillova I.A., Kirillov D.V. 2015. Reproduction biology of Gymnadenia conopsea (L.) R.Br. (Orchidaceae) on its northern distribution border. Contemporary Problems of Ecology 8(4): 512-522. DOI: 10.1134/ S1995425515040095

Kirillova I.A., Kirillov D.V. 2017a. Reproductive biology of Platanthera bifolia (L.) Rich. (Orchidaceae) on its northern distribution border (The Komi Republic). Tomsk State University Journal of Biology 38: 68-88. DOI: 10.17223/19988591/38/4 [In Russian]

Kirillova I.A., Kirillov D.V. 2017b. Dactylorhiza maculata (L.) Soó (Orchidaceae) in the Komi Republic: coenopopulation structure and repruductive biology. Proceedings of the Komi Science Centre of the Ural Division of the Russian Academy of Sciences 3(31): 5-14. [In Russian]

Kühn R., Pedersen H.ÆE., Cribb P. 2019. Field guide to the orchids of Europe and the Mediterranean. Kew: Kew Publishing. $430 \mathrm{p}$.

Kulikov P.V., Filippov E.G. 2001. Specific features of mycorrhizal symbiosis formation in the ontogeny of orchids of the temperate zone. Russian Journal of Ecology 32(6): 408-412. DOI: 10.1023/A:1012582117188

Kull T. 2002. Population dynamics of north temperate orchids. In: T. Kull, J. Arditti (Eds.): Orchid Biology: Review and Perspectives, VIII. Dordrecht: Kluwer Academic Publishers. P. 139-165.

Kull T., Sammul M., Kull K., Lanno K., Tali K., Gruber B., Schmeller D., Henle K. 2008. Necessity and reality of monitoring threatened European vascular plants. Biodiversity and Conservation 17(14): 3383-3402. DOI: 10.1007/s10531-008-9432-2

Kull T., Selgis U., Peciña M.V., Metsare M., Ilves A., Tali K., Sepp K., Kull K., Shefferson R.P. 2016. Factors influencing IUCN threat levels to orchids across Europe on the basis of national red lists. Ecology and Evolution 6(17): 6245-6265. DOI: 10.1002/ece3.2363

Øien D.I., Moen A. 2002. Flowering and survival of Dactylorhiza lapponica and Gymnadenia conopsea in the 
Sølendet Nature Reserve, Central Norway. In: P. Kindlmann, J.H. Willems, D.F. Whigham (Eds.): Trends and fluctuations and underlying mechanisms in terrestrial orchid populations. Leiden: Backhyus. P. 3-22.

Øien D.I., Pedersen B. 2003. Seasonal pattern of dry matter allocation in Dactylorhiza lapponica (Orchidaceae) and the relation between tuber size and flowering. Nordic Journal of Botany 23(4): 441-451. DOI: 10.1111/ j.1756-1051.2003.tb00418.x

Øien D.I., O’Neill J.P., Whigham D.F., McCormick M.K. 2008. Germination ecology of the boreal-alpine terrestrial orchid Dactylorhiza lapponica (Orchidaceae). Annales Botanici Fennici 45(3): 161-172. DOI: 10.5735/085.045.0301

Pfeifer M., Wiegand K., Heinrich W., Jetschke G. 2006. Long-term demographic fluctuations in an orchid species driven by weather: implications for conservation planning. Journal of Applied Ecology 43(2): 313-324. DOI: $10.1111 /$ j.1365-2664.2006.01148.x

Puchnina L.V. 2017. Status of Calypso bulbosa and Cypripedium calceolus (Orchidaceae) populations in the Pinega State Nature Reserve. Nature Conservation Research 2(Suppl.1): 125-150. DOI: 10.24189/ncr.2017.023

Red Data Book of the Russian Federation (plants and fungi). Moscow: KMK Scientific Press Ltd., 2008. 855 p. [In Russian]

Rostás M., Tautz J.Ü. 2010. Ants as pollinators of plants and the role of floral scents. In: Z. Dubinsky, J. Seckbach (Eds): All Flesh is Grass. Dordrecht: Springer. P. 149161. DOI: 10.1007/978-90-481-9316-5 6

Schiestl F.P., Glaser F. 2012. Specific ant-pollination in an alpine orchid and the role of floral scent in attracting pollinating ants. Alpine Botany 122(1): 1-9. DOI: 10.1007/ s00035-011-0098-0

Scott H.S., Carey P.D. 2002. The effects of fungicide and water application on seed germination and infection in Gymnadenia conopsea under field conditions. In: P. Kindlmann, J.H. Willems, D.F. Whigham (Eds.): Trends and fluctuations and underlying mechanisms in terrestrial orchid populations. Leiden: Backhyus. P. 155-165.

Shefferson R.P. 2006. Survival costs of adult dormancy and the confounding influence of size in lady's slipper orchids, genus Cypripedium. Oikos 115(2): 253-262. DOI: 10.1111/j.2006.0030-1299.15231.x

Shefferson R.P., Jacquemyn H., Kull T., Hutchings M.J. 2019. The demography of terrestrial orchids: life history, population dynamics and conservation. Botanical Journal of the Linnean Society 192(2): 315-332. DOI: 10.1093/botlinnean/boz084

Sletvold N., Ågren J. 2011. Nonadditive effects of floral display and spur length on reproductive success in a deceptive orchid. Ecology 92(12): 2167-2174. DOI: 10.1890/11-0791.1

Sletvold N., Ågren J. 2014. There is more to pollinator-mediated selection than pollen limitation. Evolution 68(7): 1907-1918. DOI: 10.1111/evo.12405

Sletvold N., Ågren J. 2015. Climate-dependent costs of reproduction: Survival and fecundity costs decline with length of the growing season and summer temperature. Ecology Letters 18(4): 357-364. DOI: 10.1111/ele.12417

Sletvold N., Øien D.I., Moen A. 2010a. Long-term influence of mowing on population dynamics in the rare orchid Dactylorhiza lapponica: the importance of recruitment and seed production. Biological Conservation 143(3): 747-755. DOI: 10.1016/j.biocon.2009.12.017

Sletvold N., Grindeland J.M., Ågren J. 2010b. Pollinator-mediated selection on floral display, spur length and flowering phenology in the deceptive orchid Dactylorhiza lapponica. New Phytologist 188(2): 385-392. DOI: 10.1111/j.1469-8137.2010.03296.x

Sletvold N., Grindeland J.M., Ågren J. 2013. Vegetation context influences the strength and targets of pollinator-mediated selection in a deceptive orchid. Ecology 94(6): 1236-1242. DOI: 10.1890/12-1840.1

Stroh P.A. 2019. Long-term monitoring of Green-winged Orchid (Anacamptis morio) at Upwood Meadows NNR, Huntingdonshire. British and Irish Botany 1(2): 107 116. DOI: $10.33928 /$ bib.2019.01.107

Tamm C.O. 1948. Observations on reproduction and survival of some perennial herbs. Botaniska Notiser 3: 305-321.

Tamm C.O. 1972. Survival and Flowering of Some Perennial Herbs. II. The Behaviour of Some Orchids on Permanent Plots. Oikos 23(1): 23-28. DOI: $10.2307 / 3543923$

Vakhrameeva M.G. 2000. Genus Dactylorhiza. In: V.N. Pavlov (Eds.): Biological Flora of the Moscow Region. Vol. 14. Moscow: Grif \& K. P. 55-86. [In Russian]

Vakhrameeva M.G. 2006. Ontogeny and population dynamics of Dactylorhiza fuchsii (Orchidaceae). Botanicheskii Zhurnal 91(11): 1683-1695.

Vakhrameeva M.G., Zhirnova T.V., Melnikova A.B. 2011. To the necessity of long-term monitoring of orchid rare species populations in protected areas. In: Protection and cultivation of orchids. Moscow: KMK Scientific Press Ltd. P. 96-100. [In Russian]

Vakhrameeva M.G., Varlygina T.I., Tatarenko I.V. 2014. Orchids of Russia (biology, ecology and protection). Moscow: KMK Scientific Press Ltd. 437 p. [In Russian]

Van der Meer S., Jacquemyn H., Carey P.D., Jongejans E. 2016. Recent range expansion of a terrestrial orchid corresponds with climate-driven variation in its population dynamics. Oecologia 181(2): 435-448. DOI: 10.1007/ s00442-016-3592-7

Wells T.C.E., Cox R. 1991. Demographic and biological studies on Ophrys apifera: some results from a 10 year study. In: T.C.E. Wells, J.H. Willems (Eds.): Population ecology of terrestrial orchids. Hague: Academic Publishing. P. 47-62.

Wells T.C.E., Rothey P., Cox R., Bamford S. 1998. Flowering dynamics of Orchis morio L. and Herminium monorchis (L.) R.Br. at two sites in eastern England. Botanical Journal of the Linnean Society 126(1-2): 39-48. DOI: 10.1111/j.1095-8339.1998.tb02514.x

Wraith J., Norman P., Pickering C. 2020. Orchid conservation and research: An analysis of gaps and priorities for globally Red Listed species. Ambio: 1-11. DOI: 10.1007/s13280-019-01306-7 


\title{
ВЛИЯНИЕ ПОГОДНЫХ УСЛОВИЙ НА СЕЗОННОЕ РАЗВИТИЕ, СТРУКТУРУ ПОПУЛЯЦИИ И РЕПРОДУКТИВНЫЙ УСПЕХ DACTYLORHIZA TRAUNSTEINERI (ORCHIDACEAE) В РЕСПУБЛИКЕ КОМИ (РОССИЯ)
}

\author{
И. А. Кириллова* Д. В. Кириллов \\ Институт биологии Коми НЦ УрО РАН, Россия \\ *e-mail: kirillova_orchid@mail.ru
}

Виды семейства Orchidaceae, вследствие специфических особенностей своей биологии, высокой декоративности и слабой устойчивости к антропогенным факторам, являются одними из самых уязвимых компонентов флоры. Для успешного сохранения этих редких растений необходимы всесторонние исследования их биологии и экологии, особенно ценны в этом отношении долгосрочные демографические исследования. В статье представлены результаты мониторинга редкой орхидеи, включенной в Красную книгу Российской Федерации - Dactylorhiza traunsteineri на территории Республики Коми, где вид находится на северо-восточном пределе своего распространения. Сезонное развитие вида в регионе длится с мая по август. Выявлено, что погодные факторы (температура воздуха и осадки) оказывают влияние на особенности прохождения малого и большого жизненного цикла этого вида. На размеры растений влияют погодные условия текущего и предыдущего вегетационных периодов. Количество генеративных особей в популяции оказалось положительно связано с температурой и влажностью августа предыдущего вегетационного периода. Эффективность опыления D. traunsteineri - высокая (50.4\%), при этом она отрицательно связана с температурой в период цветения и положительно - с количеством осадков. Число семян, содержащееся в коробочке данного вида (в среднем 4090 шт.), выше, чем у других представителей рода Dactylorhiza в регионе. Реальная семенная продуктивность связана с уровнем влагообеспеченности вегетационного периода. Урожай семян D. traunsteineri- высокий, от 88000 до 199000 семян на $1 \mathrm{~m}^{2}$ в разные годы исследования. Присутствие ювенильных особей (3.5-9.4\%) во все годы изучения свидетельствует об успешном семенном возобновлении в данной популяции, оно оказалось положительно связано с тремя факторами: осадками, температурой августа и урожаем семян предшествующего вегетационного периода.

Ключевые слова: влияние климата, завязываемость плодов, мониторинг, орхидные, семенная продуктивность, структура популяции 